Proposal of Enterobacteriaceae fam. nov., nom. rev. to Replace Enterobacteriaceae Rahn 1937, nom. fam. cons. (Opin. 15, Jud. Comm. 1958), Which Lost Standing in Nomenclature on 1 January 1980

\author{
WILLIAM H. EWING, ${ }^{1}$ J. J. FARMER III, ${ }^{2}$ AND DON J. BRENNER ${ }^{2}$ \\ 2364 Wineleas Road, Decatur, Georgia 30033, ${ }^{1}$ and Enteric Section, Center for Disease Control, Atlanta, \\ Georgia $30333^{2}$
}

This article proposes the family name Enterobacteriaceae nom. rev. to fill the void in nomenclature that has existed since 1 January 1980, when the name of the family was not included on the Approved Lists of Bacterial Names.

In 1937 Rahn proposed (10) the family name Enterobacteriaceae to include species which had been included in Escherichia, Salmonella, Aerobacter, Klebsiella, Proteus, Erwinia, Eberthella, and Shigella. The new family also included strains of Serratia, Pseudomonas, Flavobacterium, and Achromobacter which fermented glucose with the production of gas. All these taxa were placed in a single new genus which Rahn named Enterobacter. A type species was not designated for this newly proposed genus, and no description was specifically given by Rahn for Enterobacter or Enterobacteriaceae. In 1948 the first Bacteriological Code was officially adopted (2), and its rules became retroactive to all bacterial names. Under the new Code, both Enterobacter Rahn 1937 and Enter. obacteriaceae Rahn 1937 became illegitimate (3) because they did not conform to all the rules (2). However the name Enterobacteriaceae had become so widely used that the Judicial Commission voted in 1958 to conserve it and to designate its type genus as Escherichia $(5,7)$. Thus, in 1958, the name changed from Enterobacteriaceae Rahn 1937, based on Enterobacter Rahn 1937, to Enterobacteriaceae Rahn 1937, nom. fam. cons. (Opin. 15, Jud. Comm. 1958), based on Escherichia Castellani and Chalmers 1919 nom. gen. cons., designated type genus, (Opin. 15, Jud. Comm. 1958).

In 1979 Lapage (8) challenged the name $E n$ terobacteriaceae Rahn 1937 (he should have challenged the name Enterobacteriaceae Rahn 1937, nom. fam. cons. (Opin. 15, Jud. Comm. 1958)) even though it was the correct name of the family under the Bacteriological Code (9). This challenge was made because the name was not formed in accordance with Rules 9 and 21a of the Code (9) in that it is not a name formed by adding the suffix "-aceae" to the stem of the name of the type genus (see Minute 9 of the minutes of the 3 September 1978 meeting of the Judicial Commission [6]). We have argued (4) that this challenge based essentially on a minute of a meeting has no validity under the Bacteriological Code (9) which specifically covered the unique case of Enterobacteriaceae in Rule 21a, Opinion 15, and List 1. Lapage (8) proposed the substitute name Enterobacteraceae with its type genus Enterobacter Hormaeche and Edwards 1960. (This genus name is illegitimate; presumably the proposed family name should have been based on Enterobacter Hormaeche and Edwards 1960, nom. gen. cons. (Opin. 28, Jud. Comm. 1963), which is both legitimate and conserved.) Enterobacteriaceae Lapage 1979 was a validly published name from June 1979 to 31 December 1979; however, it was never the correct name for the family under the Bacteriological Code. If Enterobacteraceae Lapage 1979 was proposed as a synonym of Enterobacteriaceae Rahn 1937, nom. fam. cons. (Opin. 15, Jud. Comm. 1958), as indicated by Lapage, then it was illegitimate from the time it was proposed until it lost standing in nomenclature on 1 January 1980. However, we have argued (4) that the two family names are not synonyms. In this case, Enterobacteraceae Lapage 1979 was legitimate for the 6 months that it had standing in nomenclature. Neither Enterobacteriaceae Rahn 1937, nom. fam. cons. (Opin. 15, Jud. Comm. 1958) nor Enterobacteraceae Lapage 1979 appeared on the Approved Lists of Bacterial Names compiled and edited by Skerman, McGowan, and Sneath (11). In a companion paper (4) we have questioned the legality of omitting Enterobacteriaceae Kahn 1937, nom. fam. cons. (Opin. 15, Jud. Comm. 1958) from the Approved List of Names of Taxa Above the Rank of Genus (11), since this name has been the only correct one for the family under the Bacteriological Code since 1958. We have argued (4) that this was an arbitrary decision with no basis in the Bacteriological Code or in the guidelines published for compiling the list. We totally support the concept of the Approved Lists because it is a superb idea that will make searches for synonyms of new taxa much easier. If the Approved Lists had 
been compiled and published as originally stated, we would not object. However, validly published, legitimate names were arbitrarily omitted from the Approved Lists. For this reason, the Bacteriological Code must be amended to give equal priority to the omitted names. Regardless of the legality and wisdom of omitting Enterobacteriaceae Rahn 1937, nom. fam. cons. (Opin. 15, Jud. Comm. 1958), this name lost standing in nomenclature on 1 January 1980 , as did the name Enterobacteraceae Lapage 1979 (11).

Rule 28a of the Bacteriological Code allows for the revival of and reuse of names which do not appear on the Approved List of Bacterial Names. Under Rule 28a (9, p. 27), we hereby propose Enterobacteriaceae fam. nov., nom. rev. It refers to the same taxon as Enterobacteriaceae Rahn 1937, nom. fam. cons. (Opinion 15, Jud. Comm. 1958), which lost standing in nomenclature on 1 January 1980. The proposal of Enterobacteriaceae fam. nov., nom. rev. is in conformity with the Bacteriological Code, which is clear on this point. Although the family name is not formed by adding "-aceae" to the stem of the type genus as required by Rule $21 \mathrm{a}(9, \mathrm{p} .22)$, this exception is specifically covered by Rule $21 \mathrm{~b}$ $(9$, p . 22) which says: "If the name of a family was not made in conformity with Rule 21a but its name has been conserved, then the type genus may be fixed by an Opinion of the Judicial Commission. Example: the genus Escherichia is the type genus of the family Enterobacteriaceae (Opinion 15)." A similar statement appeared in Rule $9 \mathrm{~b}$ of the 1958 Code. Rule $21 \mathrm{~b}$ had as its judicial basis Principles 1, 8, and 9, Opinion 1, and List 1 of the 1975 Bacteriological Code. The choice of reviving Enterobacteriaceae rather than Enterobacteraceae, Escherichiaceae, or another name was a simple one for reasons given in some detail in a companion paper (4).

In summary, we propose: Enterobacteriaceae fam. nov. nom. rev., formerly (from 1958 to 31 December 1979) known as Enterobacteriaceae Rahn 1937, nom. fam. cons. (Opinion 15, Jud. Comm. 1958) (see also the 1975 Bacteriological Code, p. 22, 69, and 91).

Description. Small gram-negative rods; motile by peritrichous flagella or nonmotile. Do not form endospores; not acid fast. Grow in both the presence and absence of oxygen. Grow well or, peptone and meat extract media. Some members grow on D-glucose as the sole source of carbon and energy, but other strains require vitamins and/or amino acids. Not halophilic. Acid is produced during the fermentation of D-glucose, other carbohydrates, and polyhydroxylalcohols; visible gas is often produced. Catalase positive with the exception of Shigella dysenteriae O group 1; oxidase negative. Nitrates are reduced to nitrites except by some strains of Erwinia. Guanine plus cytosine content of DNA is 38 to $60 \mathrm{~mol} \%$.

The descriptive material in the eighth edition of Bergey's Manual (1) written by the late S.T. Cowan, beginning at "Further comments" on $p$. 290 and continuing to the end of "Further notes" on p. 293, also applies to Enterobacteriaceae fam. nov., nom. rev. Another criterion for deciding if a genus belongs to the family is to test by DNA-DNA hybridization the relatedness of its type species to Escherichia coli, the type species of the type genus for the family. A relatedness value of $10 \%$ or more (hydroxyapatite method, $60^{\circ} \mathrm{C}$ ) usually indicates that the new taxon belongs to the family.

Type genus: Escherichia Castellani and Chalmers 1919, nom. fam. cons. Designated type genus (Opin. 15, Jud. Comm. 1958) (see also the 1975 Bacteriological Code, p. 22, 69, 70, 91, 96, and 97).

\section{REPRINT REQUESTS}

Address reprint requests to: Center for Disease Control, Attn. J. J. Farmer III, Building 1, Room B341, Atlanta, GA 30333.

\section{LTERATURE CITED}

1. Buchanan, R. E., and N. E. Gibbons (ed.). 1974. Bergey's manual of determinative bacteriology, 8 th ed. The Williams and Wilkins Co., Baltimore.

2. Buchanan, R. E., R. St. John-Brooks, and R. S. Breed (ed.). 1948. International bacteriological code of nomenclature. J. Bacteriol. 55:287-306.

3. Editorial Board, Judicial Commission. 1951. Status of the generic name Bacterium, the specific name Bacte. rium coli and the family name Bacteriaceae. Preliminary statement, file no. 5. Int. Bull. Bacteriol. Nomencl. Taxon, 1:64-79.

4. Farmer, J. J., III, D. J. Brenner, and W. H. Ewing. 1980. Opposition to two recent proposals which would reject the family name Enterobacteriaceae and Esch. erichia as its type genus. Int. J. Syst. Bacteriol. 30:660673.

5. International Code of Nomenclature of Bacteria and Viruses. 1958. Iowa State College Press, Ames, Iowa.

6. International Committee on Systematic Bacteriology, Judicial Commission. 1979. Minutes of the meeting, 3 September 1978. Int. J. Syst. Bacteriol. 29: 267-269.

7. Judicial Commission of the International Committee on Bacteriological Nomenclature. 1968. Conservation of the family name Enterobacteriaceae, of the name of the type genus, and designation of the type species. Int. Bull. Bacteriol. Nomencl. Taxon. 8:73-74.

8. Lapage, S. P. 1979. Proposal of Enterobacteraceae nom. nov, as a substitute for the illegitimate but conserved name Enterobacteriaceae Rahn 1937. Request for an opinion. Int. J.Syst. Bacteriol. 29:265-266.

9. Lapage, S. P., P. H. A. Sneath, E. F. Lessel, V. B. D. Skerman, H. P. R. Seeliger, and W. A. Clark (ed.). 1975. International code of nomenclature of bacteria. American Society for Microbiology, Washington, D.C.

10. Rahn, O. 1937. New principles for the classification of bacteria. Zentralbl. Bakteriol. Parasitenkd. Infektionskr. Hyg. Abt. 2 96:273-286.

11. Skerman, V. B. D., V. McGowan, and P. H. A. Sneath. 1980. Approved lists of bacterial names. Int. J. Syst. Bacteriol. 30:225-420. 